\title{
Influence of carbon and alternating oxic-anoxic model on sludge bulking and pollutant removal effect
}

\author{
E.L. Jiao ${ }^{1}$, C.D Gao ${ }^{1 *}$, S.X. Fan ${ }^{1}$, R.F. Li ${ }^{1}$, Y. $\operatorname{Tian}^{1}$ \\ ${ }^{1}$ College of Environmental and Energy Engineering, Beijing University of Technology, Beijing, \\ China
}

KEYWORD: SBR; Alternating oxic-anoxic; Sludge bulking; Sodium acetate; Pollutant removal ABSTRACT: The influence of carbon and alternating oxic-anoxic model on sludge bulking and chemical oxygen demand (COD), ammonia nitrogen and total nitrogen removal effect are investigated under alternating oxic-anoxic model in sequencing batch reactor (SBR). The experiment performed for 23 days and 30 days instage 1 and 2 separately. The results showed that the average removal rate of ammonia nitrogen, total nitrogen and COD were 97.8\%, 68.1\% and 55.1\% in stage 1. The average removal rate of total nitrogen improved to $90.4 \%$ in stage 2 mainly due to that the addition of carbon source and more electron accepter, more nitrate and nitrite were reduced to nitrogen, The removal of COD reached $82.5 \%$ due to the addition of sodium acetate and the increasement of organic loading, at last the effluent met the national level A standard. The MLSS maintained steadily around 3000mg/L in stage 1 and 2, the SVI improved slowly and reached $180 \mathrm{ml} / \mathrm{g}$ at the end during stage 2, the inflow water got high concentration of small molecular compounds by addition of sodium acetate which was favor of increasement of filamentous bacterium, the SVI was affected by the amount of filamentous bacterium.

\section{INTRODUCTION}

Biological denitrification usually includes two parts: heterotrophic denitrification and autotrophic denitrification, differs in that depending on the electron donor source[1]. The heterotrophic denitrifiers needs carbon source, which utilize organic matters such as ethanol and methanol as electron donors [2]. But the domestic sewage always keeps low carbon source, which is adverse to the nitrogen removal[3]. Alternating oxic-anoxic model is favor of simultaneous nitrification-denitrification and short-cut nitrification-denitrification, which could save the energy and carbon source [4-6]. At the same time, high organic loading easily cause sludge bulking[7], so the addition amount of carbon should be tested. This study proceed in alternating oxic-anoxic model in sequencing batch reactor(SBR) and investigated the influence of carbon and alternating oxic-anoxic model on sludge b u l k i n g a n d n i t r o g e $n$ r e m o v a 1 e f $f$ e $c t$.

\section{MATERIALS AND METHODS}

\section{Experimental device}

The experimental device is a sequencing batch reactor (SBR). The total and effective volume is $10 \mathrm{~L}$ and $8 \mathrm{~L}$, the influent sewage and effluent is both $4 \mathrm{~L}$ in every cycle, and the sludge retention time is 20d. The DO concentration is controlled by a gas flow-meter and above $2 \mathrm{mg} / \mathrm{L}$ in the oxic phase. The mixed liquor suspended solids (MLSS) in the reactor maintains around $3000 \mathrm{mg} / \mathrm{L}$. The average temperature is $25^{\circ} \mathrm{C}$. The sludge came from a Beijing real sewage treatment plant.

\section{Operational condition}

The operational mode in every cycle of stage 1 and 2 is as follows: inflow $\longrightarrow$ oxic(1h) $\longrightarrow$ anoxic(1h) $\longrightarrow$ oxic(1h) $\longrightarrow$ anoxic(1h) $\longrightarrow$ oxic(1h) $\longrightarrow$ anoxic(1h) $\longrightarrow$ sediment $(0.5 \mathrm{~h}) \longrightarrow$ effluent.

The average influent COD concentration is stage 1 and 2 were 88.8 and $249.7 \mathrm{mg} / \mathrm{L}$, respectively. The addition of sodium acetate was used to increase the COD concentration in stage 2. 


\section{Water source and water quality}

The experiment used domestic sewage from a septic tank in a Beijing real residential area. The inflow water quality is shown in Table 1.

Table 1 - Wastewater characteristics

\begin{tabular}{cccccc}
\hline Item & $\mathrm{pH}$ & $\begin{array}{c}\rho(\mathrm{COD}) \\
\left(\mathrm{mg} \cdot \mathrm{L}^{-} 1\right)\end{array}$ & $\begin{array}{c}\rho\left(\mathrm{NH}_{4}{ }^{+}-\mathrm{N}\right) \\
\left(\mathrm{mg} \cdot \mathrm{L}^{-} 1\right)\end{array}$ & $\begin{array}{c}\rho\left(\mathrm{NO}_{3}^{-}-\mathrm{N}\right) \\
\left(\mathrm{mg}^{-} \mathrm{L}^{-} 1\right)\end{array}$ & $\begin{array}{c}\rho\left(\mathrm{NO}_{2}^{-}-\mathrm{N}\right) \\
\left(\mathrm{mg} \cdot \mathrm{L}^{-} 1\right)\end{array}$ \\
\hline Scope & $7.0-7.8$ & $77.6-286.7$ & $61.9-83.2$ & $0-0.9$ & $0-1.2$ \\
\hline
\end{tabular}

\section{Analysis methods}

COD was measured by quick-analysis apparatus (5B-3(A): Beijing Lian-hua Technology Co., Ltd., China). $\mathrm{NH}_{4}+-\mathrm{N}, \mathrm{NO}_{2}{ }^{-} \mathrm{N}, \mathrm{NO}_{3}{ }^{-}-\mathrm{N}$, settling velocity (SV), and the sludge volume index (SVI) were measured according to standard methods for the examination of water and wastewater (APHA, 1998). DO, $\mathrm{pH}$ and temperature are determined with a WTW dissolved oxygen meter (Multi 3420type). Gram's staining smears of bacterium were observed by an OLYMPUS BX61 fluorescence microscope.

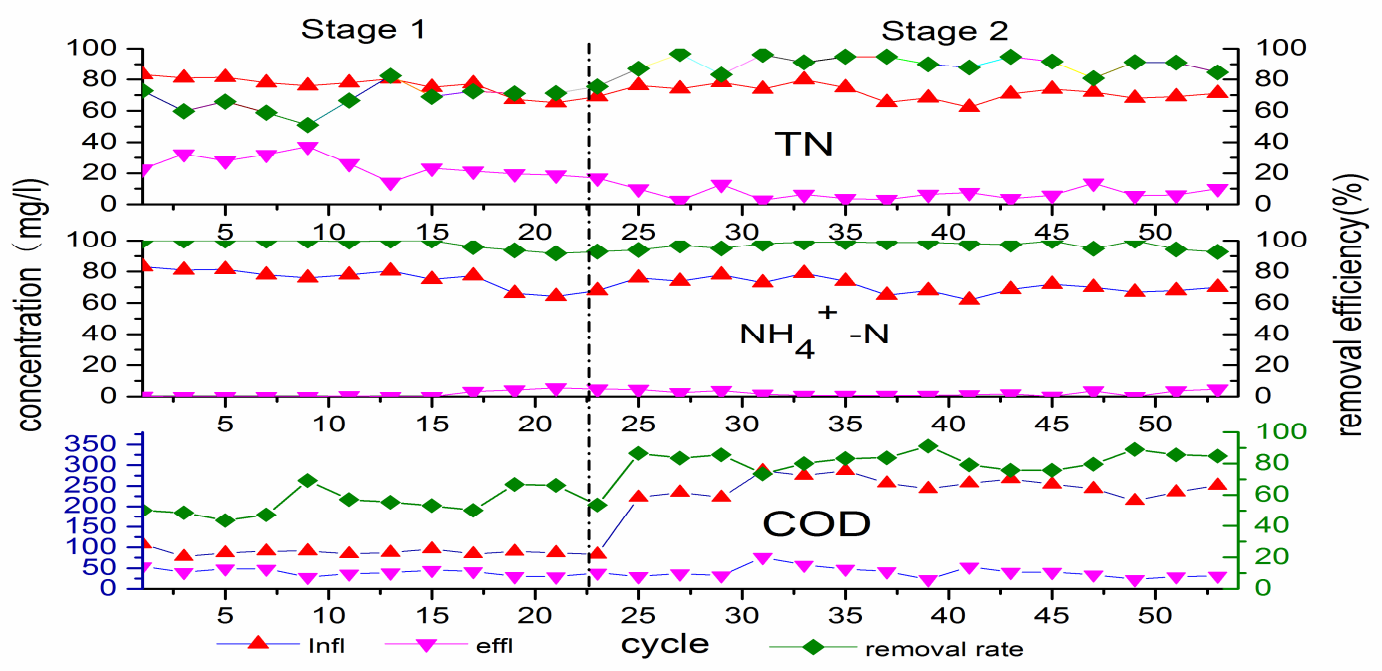

Fig. 1 ammonia nitrogen, total nitrogen and COD removal rate

\section{RESULTS AND DISCUSSION}

The experiment performed for 23 days and 30 days in stage 1 and 2 separately. The ammonia nitrogen, total nitrogen and COD removal rates were shown in Fig. 1. In the stage 1, the average concentration of influent and effluent ammonia nitrogen, total nitrogen and COD were $75.7 \mathrm{mg} / \mathrm{L}$ and $1.51 \mathrm{mg} / \mathrm{L}, 76.1 \mathrm{mg} / \mathrm{L}$ and $24.3 \mathrm{mg} / \mathrm{L}, 88.9 \mathrm{mg} / \mathrm{L}$ and $39.9 \mathrm{mg} / \mathrm{L}$ respectively. The total oxic and anoxic time were both $3 \mathrm{~h}$, because of enough DO and hydraulic retention time (HRT) of oxic phase[8], almost all ammonia nitrogen was oxidized to nitrite and nitrate, The average removal rate of ammonia nitrogen was $97.8 \%$ and the effluent ammonia nitrogen was near to 0 . But the effluent total nitrogen was higher than $15 \mathrm{mg} / \mathrm{L}$, the average removal rate of total nitrogen was $68.1 \%$, the low average removal rate due to low carbon source in the influent and short HRT of anoxic phase. The removal of COD was instability in this stage, the effluent COD was $39.9 \mathrm{mg} / \mathrm{L}$, lower than $50 \mathrm{mg} / \mathrm{L}$, and the average removal rate was $55.1 \%$. 
In the stage 2, The average concentration of influent and effluent ammonia nitrogen, total nitrogen and COD were $70.9 \mathrm{mg} / \mathrm{L}$ and $2.0 \mathrm{mg} / \mathrm{L}, 71.9 \mathrm{mg} / \mathrm{L}$ and $6.7 \mathrm{mg} / \mathrm{L}, 249.7 \mathrm{mg} / \mathrm{L}$ and $39.7 \mathrm{mg} / \mathrm{L}$ respectively. The removal rate of ammonium nitrogen kept the same level in stage 1 , and the average removal rate of ammonia nitrogen was $97.1 \%$. Because of the addition of carbon source and more electron accepter, more nitrate and nitrite were reduced to nitrogen, at the same time the alternating oxic-anoxic model was in favor of shortcut nitrification-denitrification[10], the total nitrogen removal rate improved and average removal rate increased to $90.4 \%$ in this stage, the average effluent total nitrogen was lower than $7 \mathrm{mg} / \mathrm{L}$. The removal of COD was also stability, and the average removal rate reached $82.5 \%$.Due to the addition of sodium acetate, the organic loading increased, then the COD removal rate improved[9], and the effluent COD concentration was lower than 50 $\mathrm{mg} / \mathrm{L}$, the effluent met the national level A standard.

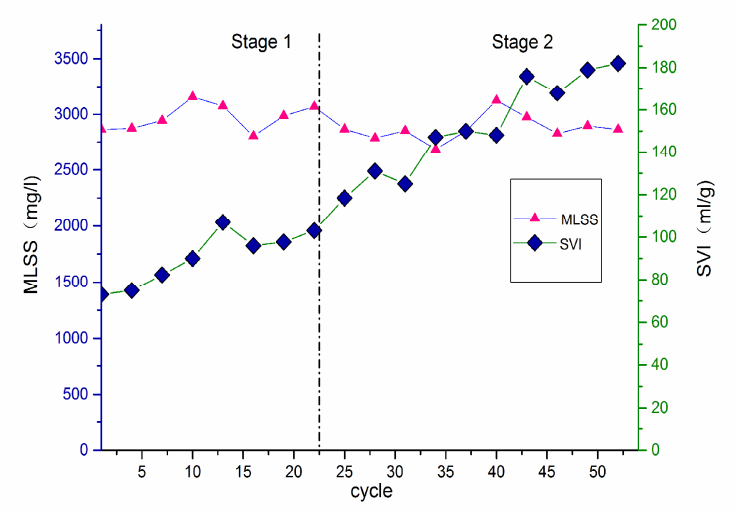

Fig. 2 The variations of SVI and MLSS
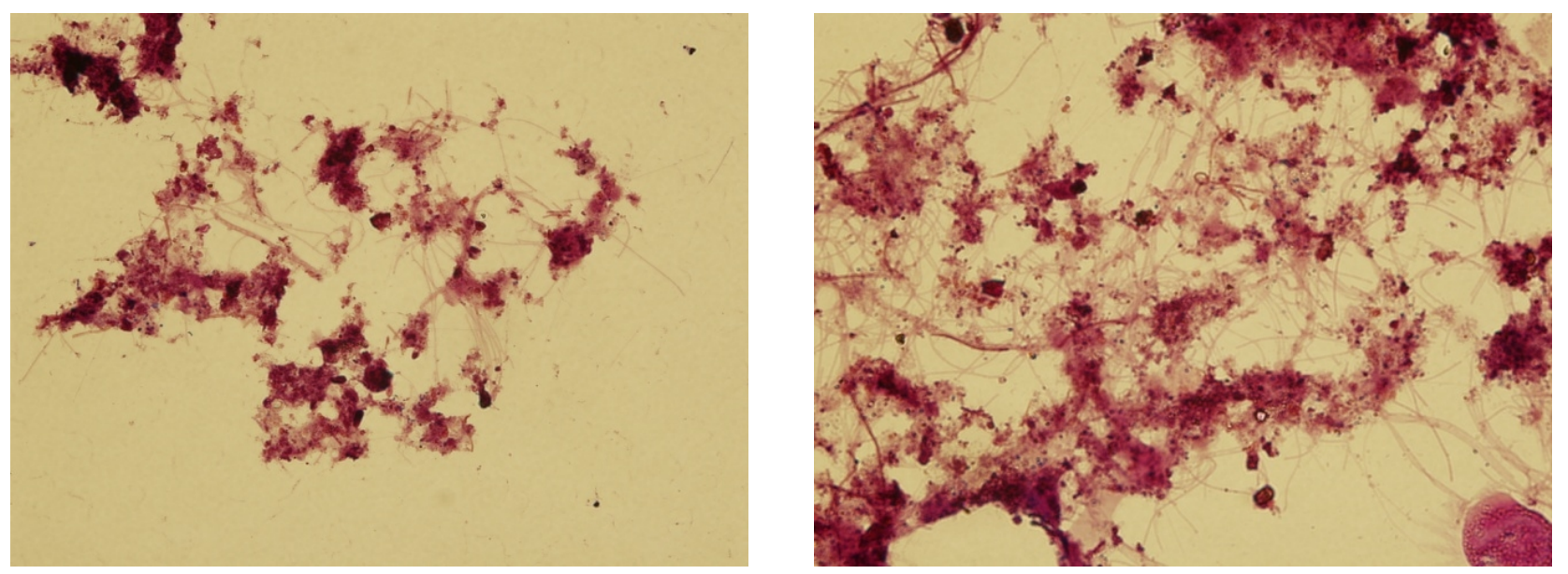

Fig.3 Images of Gram staining (1000 times) in stage1 (up) and stage2 (down)

The variations of SVI and MLSS can be seen in Fig. 2, the MLSS maintained steadily around $3000 \mathrm{mg} / \mathrm{L}$ in stage 1 and 2. But the SVI had different trend. In stage 1, the SVI was around $90 \mathrm{ml} / \mathrm{g}$ and kept steadily, then the SVI improved slowly during stage 2, the SVI reached $180 \mathrm{ml} / \mathrm{g}$ at the end, the system occurred sludge bulking. Gram's staining smears of bacterium were observed by an OLYMPUS BX61 fluorescence microscope, the images of Gram staining (1000 times) in stage1 (left) and stage2 (right) can be seen in Fig. 3, the amount of filamentous bacterium in stage 2 was larger than stage 1, the SVI was affected by the amount of filamentous bacterium, the inflow water got high concentration of small molecular compounds by addition of sodium acetate which was favor of increasement of filamentous bacterium. 


\section{CONCLUSION}

The experiment performed for 23 days and 30 days in stage 1 and 2 separately. In the stage 1, the average concentration of influent and effluent ammonia nitrogen, total nitrogen and COD were $75.7 \mathrm{mg} / \mathrm{L}$ and $1.51 \mathrm{mg} / \mathrm{L}, 76.1 \mathrm{mg} / \mathrm{L}$ and $24.3 \mathrm{mg} / \mathrm{L}, 88.9 \mathrm{mg} / \mathrm{L}$ and $39.9 \mathrm{mg} / \mathrm{L}$ respectively. The total oxic and anoxic time were both $3 \mathrm{~h}$, because of enough DO and hydraulic retention time (HRT) of oxic phase, almost all ammonia nitrogen was oxidized to nitrite and nitrate, The average removal rate of ammonia nitrogen, total nitrogen and COD were $97.8 \%, 68.1 \%$ and $55.1 \%$. In the stage 2 , because of the addition of carbon source and more electron accepter, the total nitrogen and COD removal rate improved to $90.4 \%$ and $82.5 \%$ respectively, the effluent met the national level A standard. At the same time, the SVI reached $180 \mathrm{ml} / \mathrm{g}$ due to increasement of filamentous bacterium.

\section{ACKNOWLEDGEMENTS}

This paper is supported by National Natural Science Funds of China (51478012) and General Program of Science and Technology Development Project of Beijing Municipal Education Commission of China (KM201410005009).

\section{REFERENCES}

1 S. Park, J. Seon, I. Byun, S. Cho, T. Park and T. Lee. Comparison of Nitrogen Removal and Microbial Distribution in Wastewater Treatment Process Under Different Electron Donor Conditions. Bioresource Technology. 2010, 101(9): 2988-2995.

2 B.E.RITTMANN, P.L. MCCARTY.2001. ENVIRONMENTAL BIOTECHNOLOGY: PRINCIPLES AND APPLICATIONS. MCGRAW-HILL, NEW YORK.

3 C. D. Gao, E. L. Jiao, H. Li, W. X. Wang and S. Y. Wang. Filamentous Sludge Bulking in a/O Process Treating Domestic Sewage of Low Carbon/Nitrogen Ratio. FRESENIUS ENVIRONMENTAL BULLETIN. 2013, 22(12A): 3607-3613.

4 K. Pochana and J. Keller. Study of Factors Affecting Simultaneous Nitrification and Denitrification (Snd). Water Science and Technology. 1999, 39(6): 61-68

5 M. Kornaros, S.N. Dokianakis and G. Lyberatos. Partial Nitrification/Denitrification Can Be Attributed to the Slow Response of Nitrite Oxidizing Bacteria to Periodic Anoxic Disturbances[J].Environmental Science\& Technology, 2010,44(19):7245-7253.

6 A. N. Katsogiannis, M. Kornaros and G. Lyberatos. Enhanced Nitrogen Removal in Sbrs Bypassing Nitrate Generation Accomplished by Multiple Aerobic/Anoxic Phase Pairs[J]. Water Science and Technology,2003,47(11):53-59.

7 Y.Z. Peng, C.D.Gao, S.Y.Wang, et al. Non-filamentous sludge bulking caused by a deficiency of nitrogen in industrial wastewater treatment[J].Water SciTechnol,2003,47(11) : 289-295.

8 Inhibition of Nitrification by Ammonia and Nitrous Acid[J].Water Pollution Control Federation, 1976,48(5) 835-852.

9 D.W Gao ,R An ,Y.Tao,Y. Fu,N.Q. Ren. Impact of organic loading on anoxic tank-aerobic MBR system[J]. JOURNAL OF HARBIN INSTITUTE OF TECHNOLOGY,2010,42(6):886-903.

10 D.W.Gao, Y.Z.Peng, S.Y.Wang.Impact of influent COD and ammonia mass concentration on alternating oxic-anoxic shortcut nitrification-denitrification[J]. Journal of Chemical Engineering,2006,34(7):38-41 